\title{
IMPLEMENTASI PEMBELAJARAN PENDIDIKAN AGAMA ISLAM DI INSTITUT TEKNOLOGI BANDUNG
}

\section{THE IMPLEMENTATION OF ISLAMIC EDUCATION LEARNING IN INSTITUTE OF TECHNOLOGY BANDUNG}

\author{
Juju Saepudin \\ Balai Penelitian dan Pengembangan Agama Jakarta \\ Jl. Rawa Kuning No.6 Pulo Gebang Cakung - Jakarta Timur \\ Email: saep.17.khasep@gmail.com \\ Komarudin Shaleh \\ Universitas Islam Bandung \\ Jl. Tamansari No. 1, 20, 24 Bandung \\ Email: komarudin_shaleh@unisba.ac.id
}

Naskah diterima tanggal 15 oktober 2018, Naskah direvisi tanggal 31 Oktober 2018, Naskah disetujui tanggal 5 November 2018

\begin{abstract}
Abstrak
Dampak negatif dari kemajuan ilmu pengetahuan dan teknologi serta lajunya arus modernisasi yang begitu cepat, menuntut umat manusia untuk segera membentengi diri dengan kemampuan kepribadiannya agar tidak kehilangan jati diri serta ikut terseret dalam pola globalisasi yang jauh dari nilai-nilai agama. Pendidikan agama dipandang memiliki peranan yang sangat vital dalam membangun watak dan peradaban bangsa yang bermartabat sebagi solusi mengatasi hal tersebut. Untuk itu diperlukan pelaksanaan pendidikan agama yang lebih kondusif dan prospektif terutama di perguruan tinggi yang merupakan garda terdepan dalam mengantisifasi perubahan. Tulisan ini menyajikan model implementasi pembelajaran Pendidikan Agama Islam (PAI) di Institut Teknologi Bandung (ITB). Metode pengumpulan data dengan observasi, wawancara mendalam dan dokumentasi. Hasil analisa data secara induktif dapat diketahui bahwa implementasi PAI di ITB dilakukan dengan mengacu kepada Sistem Pendidikan Nasional yang dikembangkan melalui program pembelajaran berupa character buiding yang dilakukan secara sinergi antar Sosio-Teknologi ITB, Yayasan Masjid Salman ITB dan UKM Gamais ITB. Implikasi dari hal tersebut di atas mampu membentuk sosok mahasiswa yang memiliki karakter, watak dan kepribadian serta prestasi yang disertai prestise dengan landasan keimanan dan ketakwaan serta nilai-nilai akhlak di masyarakat.
\end{abstract}

Kata kunci: Implementasi, Pembelajaran, Pendidikan Agama, Islam, ITB.

\begin{abstract}
The negative impacts of the advancement of science and technology and the rapid pace of modernization demand people to immediately fortify themselves with the ability of their personality so as not to lose their identity and be dragged into the pattern of globalization that deviates from religious values. Religious education is seen to have a very vital role in building dignified national character and civilization as a solution to overcome the problem. For this reason, it is necessary to implement a more conducive and prospective religious education, especially in universities which become the front guard in anticipating the change. This paper presents a model for the implementation of Islamic Education learning in Institute of Technology Bandung (ITB). The data were collected by observation, in-depth interviews and documentation. From the results of data which were analyzed inductively, it could be seen that the implementation of Islamic Education in ITB was carried out by referring to the National Education System developed through learning programs in the form of character buiding conducted in synergy between ITB Socio-Technology, ITB Salman Mosque Foundation and ITB Gamais UKM. The implication of that system was able to form a student figure who had the character, personality and achievement and prestige with the strong faith and piety as well as moral values in society.
\end{abstract}

Keywords: Implementation, Islamic, Education, Learning, ITB. 


\section{PENDAHULUAN}

$\mathrm{D}$ erasnya arus globalisasi yang terus mengalir, mengakibatkan gerak perubahan yang sangat cepat dan penetrasi budaya yang demikian dahsyat. Kehidupan manusia dituntut oleh waktu agar berlari cepat seperti kemajuan ilmu pengetahuan dan teknologi yang dibangun menuju puncak efisiensi dan efektifitas membawa misi perubahan kemanusiaan dan peradaban.

Perubahan yang ditimbulkannya akan berdampak pada banyaknya tantangan, ketatnya persaingan dan terbukanya peluang di berbagai jenjang pendidikan. Di beberapa Perguruan Tinggi Umum (PTU) saat ini perilaku dan kehidupan mahasiswa sangat mengerikan; mulai tawuran antar kampus, pesta narkoba hingga seks bebas sering diperlihatkan oleh mahasiswa di negeri ini. Berbagai fenomena tersebut menjadi indikator lemahnya kontrol pendidikan agama di PTU. Namun sayangnya hal itu sering dianggap hal yang biasa oleh para pemangku kebijakan. Bahkan mereka yang beragama Islampun kurang responsif dengan kenyataan tersebut. Oleh sebab itu kehadiran Pendidikan Agama Islam (PAI) sangatlah besar kontribusinya bagi kehidupan di kampus, lebih-lebih mereka yang gersang dari ajaran agama (Anshari, 2012: 81-82).

Dalam struktur kurikulum nasional pendidikan tinggi, mata kuliah PAI merupakan mata kuliah yang wajib diikuti oleh semua mahasiswa yang beragama Islam di seluruh perguruan tinggi umum, pada setiap jurusan, program dan jenjang pendidikan, baik di perguruan tinggi negeri maupun swasta. Menurut Hidayatulloh (2013: 186), hal ini mencerminkan ada itikad baik dan serius dari pemerintah dalam upaya mewujudkan peserta didik, dalam hal ini mahasiswa (sebagai generasi pelanjut pembangunan bangsa), yang berkualitas sebagaimana tercermin dalam tujuan pendidikan nasional di atas. Selanjutnya, secara normatiffungsional, penyelenggaraan Pendidikan Agama (Islam khususnya), dipandang dan diyakini secara langsung dapat memberikan kontribusi terhadap pengembangan kepribadian mahasiswa.

Mengingat pentingnya misi tersebut maka mata kuliah PAI perlu mendapatkan perhatian secara serius. PAI harus dikelola secara profesional, teratur, baik dan terencana. PAI di PTU harus mendapat perhatian yang serius,, dikelola dan dikembangkan secara profesional sehingga menghasilkan pribadi yang unggul. Sumber daya manusia yang unggul menurut pandangan Islam, bukan sekedar mampu menguasai ilmu pengetahuan dan teknologi (iptek), tetapi juga sosok individu yang mampu memadukan iptek, seni dan agama secara seimbang. Sosok individu seperti ini di dalam alQur'an disebut sosok ulul albaab, yakni sosok individu yang memiliki keseimbangan antara fikir dan dzikir (QS.3: 190-191).

Pembelajaran PAI di PTU dengan berbagai instrumennya menjadi sangat penting dan signifikan dalam rangka mewujudkan sosok individu yang berpredikat ulul albaab tersebut, sebab Perguruan Tinggi merupakan garda terdepan dalam mengantisivasi perubahan, maka mata kuliah PAI di PTU tidak hanya mengantarkan peserta didik (mahasiswa) untuk menguasai berbagai hal dalam ajaran Islam, tetapi yang terpenting adalah bagaimana peserta didik dapat mengamalkan ajaran Islam di dalam kehidupan sehari-hari, bahkan dapat digandengkan dengan jurusan atau program studi yang ditempuhnya sehingga dapat melahirkan para saintis dan teknokrat yang berkarakter islami.

$\mathrm{Di}$ Indonesia semangat membangun perguruan tinggi sedemikian besar. Hal itu terlihat dengan jelas dari jumlah perguruan tinggi yang sedemikian banyak jumlahnya. Jika dihitung, maka tidak kurang dari 3500 perguruan tinggi di Indonesia, baik yang berstatus negeri maupun yang berstatus swasta. Perguruan Tinggi Negeri (PTN), dalam arti dikelola oleh pemerintah, jumlahnya lebih dari 130 buah. Sebagian berada di bawah pengelolaan Kementerian Pendidikan dan Kebudayaan (sekarang Kemenristekdikti), sedang 52 lagi di antaranya dikelola oleh Kementerian Agama (Saepudin, 2015: 278).

Institut Teknologi Bandung (ITB) merupakan salah satu PTU yang didirikan pada tanggal 2 Maret 1959, dan diresmikan oleh Presiden RI pertama, Ir. Soekarno di kota Bandung Jawa Barat, memiliki visi dan misi ingin menjadikan Perguruan Tinggi yang unggul, bermartabat, mandiri dan diakui dunia serta memandu perubahan yang mampu meningkatkan kesejahteraan bangsa Indonesia dan dunia. Sebagai Perguruan Tinggi yang terkemuka, ITB memiliki 26 Departemen Program Sarjana; 34 Program Studi S2/ Magister; dan 3 Bidang Studi S3/Doktor. Di dalamnya tercakup unsur-unsur ilmu pengetahuan, teknologi, seni, bisnis dan ilmu-ilmu kemanusiaan.

Program Sarjana atau Strata-1 (S1) dirancang selesai dalam 4 tahun dengan gelar Sarjana Teknik, Sarjana Sains, Sarjana Seni, Sarjana Desain, Sarjana Farmasi, dan Sarjana Manajemen, dengan beban SKS sekurang-kurangnya 144 SKS dan sebanyak- 
banyaknya 160 SKS. Dari sejumlah SKSitu di dalamnya terdapat 3 (tiga) SKS untuk mata kuliah Pendidikan Agama Islam.

Berdasarkan data dari bagian akademik, pada tahun 2012, ITB memiliki jumlah mahasiswa S-1 sebanyak 13.503 mahasiswa; jumlah dosen 1.022 orang. Dari jumlah dosen 1.022 itu yang mengampu mata kuliah PAI sebagai tenaga tetap (PNS) hanya 5 (lima) orang dosen. Jika melihat rasio antara jumlah mahasiswa yang mengikuti perkuliahan PAI dengan jumlah dosen pengampu mata kuliah PAI, dan beban SKS yang tersedia hanya 3 SKS, maka proses pembelajaran PAI di ITB sangat tidak memadai dan cenderung tidak efektifdalam membentuk peserta didik yang beriman dan bertaqwa. Namun, fenomena yang muncul di dalam kehidupan sosial kemasyarakatan, banyak dijumpai alumni-alumni ITB yang memiliki pemahaman Ilmu Agama (Islam) yang cukup baik.

Sebagai bukti misalnya, banyak di antara mereka (para alumni) yang aktif mengampu mata kuliah PAI di Perguruan Tinggi seperti Universitas Islam Bandung (UNISBA), Universitas Pasundan (UNPAS) dan yang lainnya, mereka juga banyak yang aktif menjadi khatib Jum'at dan penceramah yang dipandang baik, aktif di berbagai organisasi keagamaan (Islam). Bahkan aktifisaktifis Yayasan Dakwah Malayasia dan Indonesia (YADMI) banyak dari alumni ITB.

Fenomena ini memunculkan pertanyaan: Bagaimana implementasi pembelajaran PAI di ITB sehingga dapat menghasilkan alumni yang mampu memahami agama Islam dengan baik. Padahal jika melihat rasio di atas cenderung tidak signifikan. Berdasarkan fenomena di atas, maka peneliti merasa tertarik untuk melihat lebih dekat dan dalam tentang fenomena tersebut melalui penelitian yang dikemas dalam sebuah judul: "Implementasi Pembelajaran Pendidikan Agama Islam di Institut Teknologi Bandung-ITB.

Pokok permasalahan dalam penelitian ini dirumuskan dalam 3 pertanyaan penelitian sebagai berikut: 1) Bagaimana program atau kebijakan pembelajaran PAI di ITB?., 2) Bagaimana Implementasi proses pembelajaran PAI di ITB?; 3) Bagaimana hubungan kelembagaan antara ITB, Yayasan Mesjid Salman, dan GAMAIS dalam proses pembelajaran PAI?. Penelitian ini bertujuan untuk memperoleh data tentang program atau kebijakan dan proses pembelajaran Pendidikan Agama Islam di ITB serta mengetahui tentang hubungan kelembagaan antara ITB, Yayasan Mesjid Salman ITB, dan GAMAIS-ITB dalam proses Pembelajaran Pendidikan Agama Islam di ITB.
Secara teoritis, penelitian ini diharapkan dapat bermanfaat bagi pengembangan Ilmu Pendidikan Agama Islam di Perguruan Tinggi Umum khususnya di ITB. Sementara secara praktis, penelitian ini diharapkan dapat membantu para pengelola Pendidikan Agama Islam, Direktorat Dirjen Pendis cq Direktorat Diktis Kementerian Agama RI.

\section{Tinjauan Pustaka \\ Hakikat Implementasi}

Implementasi program atau kebijakan merupakan salah satu tahap yang penting dalam proses kebijakan publik. Suatu program kebijakan harus diimplementasikan agar mempunyai dampak dan tujuan yang diinginkan.

Wahap dalam Setyadi (2005) mengutip pendapat para pakar yang menyatakan bahwa proses implementasi program atau kebijakan tidak hanya menyangkut perilaku badan administratif yang bertanggung jawab untuk melaksanakan program dan menimbulkan ketaatan pada diri kelompok sasaran, tetapi juga menyangkut jaringan kekuatan-kekuatan politik, ekonomi dan sosial yang langsung atau tidak langsung dapat mempengaruhi perilaku semua pihak yang terlibat, dan pada akhirnya berpengaruh terhadap dampak negatif maupun positif. Dengan demikian dalam mencapai keberhasilan implemetasi, diperlukan kesamaan pandangan tujuan yang hendak dicapai dan komitmen semua pihak untuk memberikan dukungan.

Keberhasilan implementasi suatu kebijakan, dapat diukur dengan melihat kesesuaian antara pelaksanaan atau penerapan kebijakan dengan desain, tujuan dan sasaran kebijakan itu sendiri serta memberikan dampak atau hasil yang positif bagi pemecahan permasalahan yang dihadapi.

Di dalam teori implementasi sebagaimana dikemukakan oleh Edward III (1980) dan Emerson, Grindle, serta Mize, terdapat empat variabel kritis dalam implementasi kebijakan publik atau program: 1) komunikasi atau kejelasan informasi, konsistensi informasi (communications), 2) ketersediaan sumber daya dalam jumlah dan mutu tertentu (resources), 3) sikap dan komitment dari pelaksana program atau kebijakan birokrat (disposition), dan 4) struktur birokrasi atau standar operasi yang mengatur tata kerja dan tata laksana (bureaucratic structure).

\section{Pembelajaran Pendidikan Agama Islam}

Belajar dan pembelajaran merupakan suatu istilah yang memiliki keterkaitan yang sangat erat dan tidak dapat dipisahkan satu sama lain dalam proses pendidikan. Pembelajaran seharusnya merupakan kegiatan yang dilakukan untuk 
menciptakan suasana atau memberikan pelayanan agar peserta didik belajar. Jika seorang pendidik dapat memahami proses pemerolehan pengetahuan, maka pendidik tersebut akan dapat menentukan strategi pembelajaran yang tepat (Saepudin, 2015: 227).

Pembahasan tentang pembelajaran PAI terkait erat dengan sikap keberagamaan seseorang (religiousitas). Artinya bahwa proses pembelajaran PAI harus melahirkan perubahan sikap yang diarahkan pada sikap keberagamaan. Sikap keberagamaan (religiusitas) bukan hanya menyangkut pengetahuan, tetapi juga ketundukkan dan ketaatan (pengamalan keagamaan). Menurut istilah yang diungkapkan oleh Zakiyah Darajat (1993) adalah religious consiuosnes dan religious experience".

Dalam hal ini unsur internalisasi agama ke dalam diri seseorang merupakan sesuatu yang harus diperhatikan dalam proses pembelajaran. Oleh karena itu, aspek keyakinan merupakan salah satu komponen sikap yang harus didahulukan dalam pembelajaran PAI. Karena keyakinan yang dimiliki oleh seseorang akan menimbulkan sikap tertentu. Ia akan memberikan kesetujuan atau ketidak-setujuan terhadap suatu dimensi yang ia pilih (Zamroni, 1992: 11-12).

Dengan demikian, proses pembelajaran mencakup tingkah laku, tingkah laku berubah dari tingkat yang sederhana sampai ke tingkat kompleks, kemudian dilakukan kontrol terhadap perubahan itu baik secara internal oleh diri sendiri maupun oleh faktor eksternal.

Menurut Imran Siregar (2016: 266-267), pembelajaran pendidikan agama di perguruan tinggi, berbeda dengan pola pembelajaran pendidikan agama di tingkat dasar dan menengah. Sebagai orang dewasa, mahasiswa telah memiliki banyak pengalaman, pengetahuan, kecakapan, dan kemampuan mengatasi permasalahan hidup secara mandiri yang diperoleh dari pendidikan dan pengalaman sebelumnya. Dengan demikian, teori belajar orang dewasa andragogi yang dikembangkan oleh Knowles adalah pilihan utama dalam pembelajaran mahasiswa yang mendorong kegiatan belajar mandiri dan bukan merupakan kegiatan seorang dosen mengajarkan sesuatu (Learner Centered Training/Teaching).

\section{Teori Struktural Fungsional}

Penelitian ini menggunakan teori fungsional struktural yang dicetuskan oleh Talcott Parson. Asumsi dasar dari teori fungsional struktural, salah satu paham atau prespektif di dalam sosiologi yang memandang masyarakat sebagai satu sistem yang terdiri dari bagian-bagian yang saling berhubungan satu sama lain dan bagian yang satu tidak dapat berfungsi tanpa adanya hubungan dengan bagian yang lainya (Parson, 1994: 28-29).

Teori struktural fungsional, menggambarkan bahwa struktur merujuk pada seperangkat unitunit yang relatif stabil dan berpola, atau suatu sistem dengan pola-pola yang relatif abadi. Adapun fungsi sebagai konsekuensi-konsekuensi dari setiap kegiatan yang tertuju pada adaptasi suatu struktur tertentu dari bagian komponen-komponennya. Sekalipun antar unsur itu sesekali terjadi ketegangan, penyimpangan atau disfungsi, namun pada satu saat keadaan tersebut akan dapat diatasi melalui adaptasi dan proses institusional (Nasikiun, 1996: 10).

Sementara itu, Elias M Awad dalam Amirin (1996: 22) menyebutkan, bahwa ciri-ciri sistem itu: bersifat terbuka; terdiri dari dua atau lebih subsistem; adanya saling ketergantungan, memiliki kemampuan untuk menyesuaikan diri dengan lingkungan (selfadjustment); mempunyai kemampuan untuk mengatur diri sendiri (self-regulation) dan mempunyai tujuan atau sasaran yang ingin dicapai. Sejalan dengan itu, William dan Voich Amirin (199654) juga menyebutkan, bahwa sistem itu mempunyai karakteristik yang mengarah pada satu tujuan (purposive behavior); suatu keselurahan yang bulat dan utuh (wholism); melakukan kegiatan transformasi; saling berkaitan; dan mempunyai mekanisme kontrol.

Hubungan fungsional antara komponenkomponen dalam proses pembelajaran Pendidikan Agama Islam dapat dilihat pada gambar di bawah ini :

Gambar 1. Hubungan Fungsional Antara Komponen-komponen

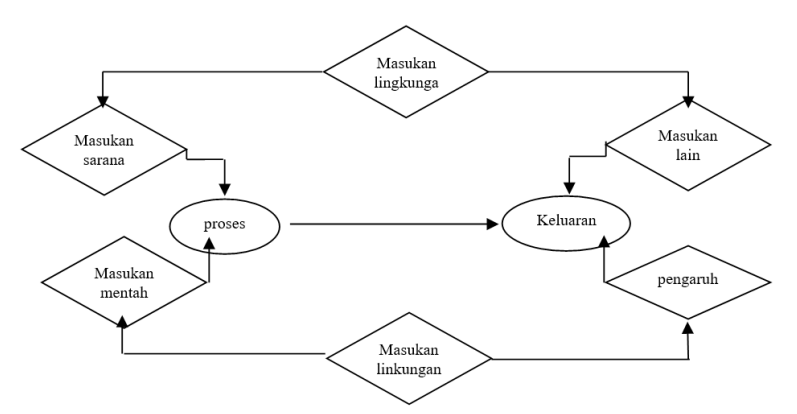

\section{METODE PENELITIAN}

Penelitian ini menggunakan pendekatan kualitatif, dengan metode studi kasus. Menurut Arikunto dalam Imam Gunawan (2013: 115) studi kasus merupakan salah satu jenis pendekatan 
deskriptif, penelitian yang dilakukan secara intensif, terperinci, dan mendalam terhadap suatu organisme (individu), lembaga atau gejala tertentu dengan daerah atau subjek yang sempit.

Penelitian kualitatif ini lebih ditekankan pada instrumen dan analisis data penelitian, guna melengkapi temuan-temuan di lapangan. Dengan pendekatan ini, diharapkan dapat menghasilkan suatu gambaran tentang Implementasi Pembelajaran Pendidikan Agama Islam di ITB secara utuh. Adapun metode yang digunakannya adalah studi kasus, yang diarahkan pada proses pembelajaran Pendidikan Agama Islam di ITB. Sudarman Danim $(2000 ; 189)$ mengatakan, bahwa studi kasus seringkali digunakan dalam penelitian program atau kebijakan sebagai studi yang cepat, biaya efisien dan ada ruang yang memungkinkan bagi analisis impresionistik dari sebuah situasi.

Alasan peneliti menggunakan jenis penelitian studi kasus karena dalam penelitian ini obyek yang diamati adalah suatu kasus yang istimewa dan memiliki keunikan tersendiri. Dalam hal ini peneliti langsung terjun ke lapangan dimana penelitian dilaksanakan, kemudian melakukan pendekatan terhadap orang-orang yang akan dijadikan sumber informasi, sehingga dapat diperoleh data-data secara keseluruhan baik lisan maupun tulisan.

Data dalam penelitian ini dikumpulkan dengan berbagai teknik, anta lain: 1) Wawancara, digunakan untuk mengungkap proses pembelajaran PAI yang dilakukan oleh pengelola atau dosen di ITB. Wawancara dilakukan secara langsung tatap muka secara individual, melalui tanya jawab secara verbal dengan pihak pengelola (SosTek), dosen pengajar, asisten, mahasiswa, dan alumni. 2) Observasi, yaitu mengamati secara langsung terhadap fenomena yang terjadi di lapangan (ITB-Yayasan Mesjid SalmanGabungan Mahasiswa Islama). 3) Dokumentasi, yang merupakan data pendukung yang mempunya hubungan dengan tema penelitian ini.

Data-data tersebut diharapkan dapat memberikan gambaran umum terhadap permasalahan yang diteliti. Pada saat observasi berlangsung, pendekatan wawancara juga dilakukan secara bersamaan sesuai dengan permasalahan penelitian. Setelah data terkumpul, baik data primer maupun data sekunder kemudian dilakukan analisis data. Bogdan dan Biken yang dikutip oleh lexy J. moleong (2009) menyatakan bahwa analisis data kualitatif adalah upaya yang dilakukan dengan jalan bekerja dengan data, mengorganisasikan data, memilah-milihnya menjadi satuan yang dapat dikelola, mensistesiskannya, mencari dan menemukan pola, menemukan apa yang penting dan apa yang dipelajari, dan memutuskan apa yang dapat diceritakan kepada orang lain.

Pertama, analisis data observasi yang dilakukan pada awal penelitian dengan harapan mencerminkan permasalahan nyata mengenai implementasi pembelajaran PAI di ITB. Kedua, analisis terhadap data dokumentasi yang berkaitan dengan masalah penelitian untuk mendukung data observasi. Ketiga, analisis terhadap data wawancara yang dipadukan dengan hasil penelitian terdahulu.

\section{PEMBAHASAN}

\section{Selayang Pandang Institut Teknologi Bandung}

Berdasarkan data dokumentasi yang diperoleh, Institut Teknologi Bandung yang disingkat ITB, didirikan pada tanggal 2 Maret 1959 di Kota Bandung Jawa Barat dan diresmikan oleh Presiden RI pertama, Ir. Soekarno. Kampus utama ITB saat ini merupakan lokasi dari Sekolah Tinggi Teknik (STT) pertama di Indonesia. Walaupun masing-masing institusi pendidikan tinggi yang mengawali ITB memiliki karakteristik dan misi masing-masing, semuanya memberikan pengaruh dalam perkembangan yang menuju pada pendirian ITB.

Sejarah ITB bermula sejak awal abad kedua puluh, atas prakarsa masyarakat penguasa waktu itu. Gagasan mula pendirianya terutama dimaksudkan untuk memenuhi kebutuhan tenaga teknik yang menjadi sulit karena terganggunya hubungan antara negeri Belanda dan wilayah jajahannya di kawasan nusantara, sebagai akibat pecahnya perang dunia pertama. De Techniche Hoogeschool te Bandung berdiri tanggal 3 Juli 1920 dengan satu fakultas de Faculteit van Technische Wetenschap yang hanya mempunyai satu jurusan de afdeeling der Weg en Waterbouw.

Didorong oleh gagasan dan keyakinan yang dilandasi semangat perjuangan proklamasi kemerdekaan serta wawasan ke masa depan, Pemerintah Indonesia meresmikan berdirinya Institut Teknologi Bandung pada tanggal 2 Maret 1959. ITB lahir dalam suasana penuh dinamika mengemban misi pengabdian ilmu pengetahuan dan teknologi, yang berpijak pada kehidupan nyata di bumi sendiri di bumi bagi kehidupan dan pembangunan bangsa.

Institut Teknologi Bandung sebagai instansi pemerintah dalam bentuk Jawatan Negeri pada tanggal 26 Desember 2000, melalui PP. No. 155 tahun 2000, Pemerintah telah menetapkan Institut Teknologi Bandung sebagai suatu Badan Hukum Milik Negara. Perguruan Tinggi Negeri dengan status Badan 
Hukum adalah sesuatu tanpa preseden dalam sejarah Pendidikan Tinggi di Indonesia. Hal ini diawali dengan terbitnya PP No. 61 tahun 1999 tentang Penetapan Perguruan Tinggi Negeri sebagai Bahan Hukum yang kemudian disusul diterbitnya PP No. 155 tahun 2000 tentang Penetapan Institut Teknologi Bandung menjadi Bahan Hukum Milik Negara. Maka dengan terbitnya PP 155 tersebut, sejak tanggal 26 Desember 2000 yang lalu ITB resmi menjadi Badan Hukum sebagaimana layaknya badan hukum lainnya yang dibenarkan melaksanakan segala perbuatan hukum yang tidak melanggar hukum serta peraturan perundang-undangan yang berlaku.

Pertimbangan pertama yang ditinjau dalam PP No. 61 secara singkat adalah adanya globalisasi yang menimbulkan persaingan yang tajam. Maka untuk meningkatkan daya saing nasional dibutuhkan PT yang dapat membangun masyarakat madani yang demokratis dan mampu bersaing secara global. Untuk itu Perguruan Tinggi (termasuk ITB), harus memperoleh kemandirian, otonomi dan tanggung jawab yang lebih besar. Penekanannya pada adanya proses globalisasi.

ITB berlokasi di kota Bandung sebuah kota di Jawa Barat yang berjarak $180 \mathrm{~km}$ dari Jakarta (Pusat Pemerintahan) dengan jumlah penduduk kurang lebih 5 (lima) juta orang. Secara fakta dan angka jumlah mahasiswa ITB sangat dinamis berikut ini data mahasiswa ITB tiga tahun terakhir:

Tabel 1. Data Mahasiswa Tiga Tahun Terakhir

\begin{tabular}{rlrrrrrrrrr}
\hline \multirow{2}{*}{ No } & \multirow{2}{*}{ Jenjang Prodi } & \multicolumn{3}{c}{ Jumlah Mahasiswa } & \multicolumn{3}{c}{ Penerimaan } & \multicolumn{3}{c}{ Kelulusan } \\
\cline { 2 - 11 } & & 2010 & 2011 & 2012 & 2010 & 2011 & 2012 & 2010 & 2011 & 2012 \\
\hline 1 & Strata 1 & 13.403 & 13.595 & 13.503 & 3.120 & 3.128 & 3.182 & 2.514 & 2.698 & 3.297 \\
2 & Strata 2 & 3.592 & 4.243 & 4.642 & 1.078 & 1.492 & 2.070 & 1.067 & 1.546 & 1.946 \\
3 & Strata 3 & 465 & 536 & 626 & 77 & 112 & 201 & 70 & 59 & 98 \\
\hline \multicolumn{1}{c}{ Total } & \multicolumn{1}{c}{} & & & & & & & & \\
\hline
\end{tabular}

Sumber: Bagian Akademik (2012).

Setiap mahasiswa yang beragama Islam, wajib mengikuti pembelajaran mata kuliah PAI. Jumlah keseluruhan mahasiswa yang mengambil PAI pada tahun 2012 kurang lebih 1000 orang. Sebelum pengambilan mata kuliah PAI, terlebih dahulu mahasiswa di test tentang BTQ (Baca Tulis AlQur'an) sekaligus dangan tahsin nya sebagai alat untuk mengukur kemampuan rata rata mahasiswa tersebut dan pada gilirannya dapat memudahkan penerapan pengajaran PAI itu sendiri, terutama dalam sistem mentoring.

Tenaga pengajar PAI di ITB, terdiri dari dosen tetap, dosen luar biasa dan assisten dosen. Dosen tetap (PNS) diangkat berdasarkan SK dosen PAI dari Dirjen Dikti, semuanya berjumlah 5 (lima) orang. Adapun dosen luar biasa yang berjumlah 9 (sembilan) orang di angkat berdasarkan SK Rektor. Setiap dosen di bantu oleh satu orang Koordinator Assisten Dosen dan dua orang Koordinator Mentoring yang di angkat dan diberi SK oleh Rektor. Sedangkan Asisten Dosen diangkat oleh Koordinator Asisten lewat Koordinator Mentoring, semuanya berjumlah 18 orang. Pengangkatan asisten, dipersiapkan oleh Koordinator Mentoring yang ada di Salman ITB kemudian direkrut oleh Koordinator Asisten yang ada di ITB. Jadi pengkoordinasian ini bisa dikatakan sebagai brige (jembatan antara ITB dengan Salman). Dalam hal ini, koordinator Asisten dengan koordinator Mentoring sangat erat kaitannya dan punya peran yang sangat penting dalam pencapaian visi dan misi serta tujuan yang ingin di capai oleh pembelajaran PAI di ITB.

Kegiatan yang dilakukan oleh asisten kebanyakannya dilakukan di Mesjid Salman, biasanya pada hari Sabtu dan Minggu. Mahasiswa banyak mendapatkan ilmu dan pemahaman agama lewat mentoring. Berdiskusi tentang masalah fikih, ekonomi syariah masalah yang sedang berkembang dan lain-lain. Jadi keberadaan Asisten Dosen PAI ini keberadaannya sangat urgen dan membantu bagi tercapainya target yang diharapkan oleh pembelajaran mata kuliah PAI di ITB.

\section{Kebijakan dan Program Mata Kuliah Pendidikan Agama Islam di ITB}

Mata kuliah PAI di ITB dilaksanakan berdasarkan Surat Keputusan Dirjen Dikti Depdiknas RI tahun 2006 Nomor 43/Dikti/ Kep/2006. Mata kuliah ini wajib diikuti oleh mahasiswa program Strata (S-1) dengan tujuan membentuk peserta didik yang beriman dan bertaqwa kepada Allah SWT (Hablumminallah) 
dan berakhlak karimah (hablumminannas) serta memiliki sumber daya manusia yang handal (ulil albab) sehingga tersedia saintis dan teknokrat yang berkarakter Qur'ani.

Visi mata kuliah PAI di ITB adalah menjadikan mata kuliah Pendidikan Agama Islam sebagai mata kuliah yang sangat diapresiasi oleh mahasiswa. Sehingga mereka mengikuti maka kuliah PAI dengan dilandasi motif instrinksik untuk mendapatkan pencerahan, bukan sekedar mendapat nilai indek prestasi. Sedangkan misi mata kuliah PAI di ITB adalah: 1) melakukan setting otak (mindset) melalui pencerahan tentang Islam holistik; 2) mengawal perubahan perilaku (behavior change) yang terjadi selama studi dan pasca studi; 3 ) memotivasi mahasiswa agar menjadikan nilai Islam sebagai landasan pengembangan sain, teknologi, dan seni sebagai jembatan terwujudnya peradaban Islami.

Berdasarkan poin-poin tersebut di atas, kebijakan-kebijakan fakultas mengenai pembelajaran mata kuliah PAI yang tertuang dalam visi dan misi, secara institusional ITB mengacu kepada Sistem Pendidikan Nasional dengan tujuan mencetak peserta didik (mahasiswa) untuk menguasai sains dan teknologi dengan kepribadian takwa, sesuai visi dan misi Islam yang rahmatan lil'alamiin.

Di ITB, perkuliahan PAI berada di bawah koordinasi Sosio-Teknologi. Sosio Teknologi merupakan koordinator di tingkat institut yang membawahi Sosio-Religi, Sosio-Dinamika dan Sosio-Komunikasi. Kelompok Sosio-Religi inilah yang bertanggung jawab penuh terhadap perkuliahan agama di ITB, termasuk agama Islam. Salah satu tugasnya adalah membuat silabi perkuliahan agama yang akan dipakai sebagai pemandu perkuliahan (Munip, 2008: 17).

Pada awalnya pengelolaan pembelajaran PAI berada di bawah tanggung jawab BPU (Biro Perkuliahan Umum), kemudian beralih menjadi tanggung jawab UP3U (Unit Program Pelaksanaan Perkuliahan Umum). Beberapa waktu kemudian berubah menjadi tanggung jawab MKDU-di Fakultas MIFA dan Sekarang bergabung dengan Sostek (Sosial-teknologi) - di Fakultas Seni Rupa dan Desain (FSRD) dan termasuk pada wilayah Humaniora.

Secara kelembagaan, mata kuliah PAI di ITB dikelola oleh bagian Sostek karena berada pada wilayah kajian sosial bersama-sama dengan mata kuliah bahasa. Saat ini mata kuliah PAI di ITB termasuk Matakuliah
Dasar Umum (MDU) Matakuliah Pengembangan Kepribadian (MPK) Sub Bidang Agama.

Menurut Ikun (Dosen PAI), Mata Kuliah PAI di ITB hanya diberikan dalam satu semester, yaitu pada semester III, dengan bobot 3 SKS, namun dalam prakteknya secara formal tatap muka di dalam kelas hanya 2 SKS (untuk materi 'aqidah dan Ibadah) dan dilengkapi dengan diskusi kelas secara terprogram serta tugas terstruktur yaitu membuat makalah sesuai dengan silabi. Sedangkan yang 1 SKS lagi dilaksanakan dalam bentuk praktek Ibadah dan kegiatan mentoring serta Asistensi Agama dan Etika Islam (AAEI) yang biasa dilaksanakan di Mesjid Salman ITB (Wawancara, 02 Agustus 2012).

Seluruh mahasiswa wajib mengikuti mata kuliah PAI pada semester yang sama, tetapi kalau bentrok dengan mata kuliah lain diperbolehkan untuk memilih jam dan kelas yang berbeda (sifatnya fleksible).

\section{Implementasi Proses Pembelajaran Pendidikan Agama Islam di ITB}

Kemajuan teknologi dan ilmu pengetahuan menjadikan sistemyangdianutoleh setiap Perguruan Tinggi haruslah berangsur diubah. Seiring dengan kebutuhan dan tuntutan tersebut, perubahan kurikulum ini menjadi upaya untuk pengembangan inovasi terhadap suatu tuntutan tersebut. Kurikulum PAI di Perguruan Tinggi mengalami beberapa kali perubahan dari bentuk kurikulum yang sangat sederhana sampai semi sempurna. Pasca penerapan KBK, KTSP yang cukup lama, baru baru ini muncul ide tentang KKNI di perguruan tinggi-sebuah langkah serius konseptualisasi kurikulum untuk penguatan kelembagaan yang identik dengan tiga unsur Tri Dharma Perguruan Tinggi; Pendidikan dan pengajaran, penelitian, dan pengabdian pada masyarakat (Sulaiman, 2015: 25).

Secara umum, tujuan mata kuliah PAI di ITB, adalah: Pertama, meningkatkan wawasan mahasiwa tentang Islam holistic dengan paradigma berpikir yang benar (kognitif). Kedua, meningkatkan keimanan mahasiswa kepada Allah SWT dan Rasul-Nya; antara lain ditandai dengan semangat melakukan studi keislaman yang lebih lanjut di luar kampus (afektif). Ketiga, memotivasi mahasiswa untuk melaksanakan nilai-nilai Islam, baik ibadah individual, ibadah populasi, ibadah komunitas, maupun ibadah ekosistem, termasuk menggunakan landasan nilai-nilai Islam dalam pengembangan sain dan teknologi.

Oleh sebab itu, pada hakikatnya PAI di ITB bukan sekedar transfer of knowledges atau transfer of values, tetapi merupakan aktivitas character building 
(pembentukan karakter, kepribadian). Kuliah PAI adalah proses perubahan, mengembangkan potensi yang dimiliki mahasiswa (potential capacity) menjadi kemampuan nyata (actual ability) dan tetap berada dalam posisi suci bersih (fitrah) dan lurus kepada Allah (hanief).

Menurut Ausof dalam Muslim (2016: 5) di ITB ada beberapa kompetensi yang ingin dicapai PAI dalam perkuliahannya, yaitu: 1) Mahasiswa dapat berfikir paradigmatikdan bertindak rasional; 2) manusia sanggup memenej atau mengsinergikan IQ, EQ dan SQ secara baaik; 3) mahasiswa sanggup mengaplikasikan nilai-nilai social Islam dalam pengembangan Ilmu Pengetahuan, Teknologi dan Seni. Semuan kompetensi tersebut di atas berlandaskan pada frame of reference berupa hubungan al-Qur'an dan sainswork kebijakan nasional tentang perkuUahan Pendidikan Agama Islam di PTU yang tercermin daIam SK Dirjen Dikti Depdiknas No: 43/DIKTI/Kep/2006 tentang Rambu-Rambu Pelaksanaan Kelompok MatakuUah Pengembangan Keptibadian di Perguruan Tinggi, tertanggaI 2 Juni 2006.

Secara komprehensif hakikat PAI adalah proses pengajaran dan pembimbingan peserta didik (mahasiswa) agar menjadi manusia yang memiliki ilmu pengetahuan, terpelihara fitrah dan kehanifannya sehingga menjadi manusia yang beradab, yaitu manusia yang sanggup mengatasi persoalan yang dihadapinya secara beradab tidak bergaya jahiliyah. Selanjutnya, menjadi masyarakat yang memiliki kemampuan untuk menata kehidupan dan mengatasi segala persoalan hidupnya dengan tepat dan beradab.

Pembentukan character building di ITB dilakuan melalui proses pembelajaran mata kuliah PAI melalui beberapa tahap sebagai berikut: Pertama, berkepribadian ilahiyah, yaitu manusia yang segala kemauan (willingness), perasaan (feeling), dan pikiran (thinking) nya mau di atur, tunduk dan patuh kepada aturan Allah SWT. Kedua, berpikir paradigmatik, yaitu berpikir yang berpola, memiliki rujukan, dan menggunakan referensi, bersifat rasional, komprehensif, kohern, konsisten (istiqomah) dan mendalam. Ketiga, bertindak rasional, yaitu dengan menggunakan rasio, logika, dan nalar yang benar. Keempat, melahirkan sainteks, yaitu mampu mengembangkan sains, teknologi, dan seni yang bermanfaat bagi orang banyak, target antaranya adalah maslahat didunia, sedangkan target akhirnya adalah surga.
Dari pembentukan karater tersebut diharapakan akan mumunculkan beberapa karakter yang menjadikan ciri khas mahasiswa ITB, yaitu: 1) Iman, antara lain meyakini sepenuh hati tanpa sedikitpun ragu bahwa Al-Islam merupakan satu-satunya tatanan hidup yang diwahyukan Allah Swt berisi nilai-nilai kebenaran yang absolute; 2 Islam, komitmen dan pasrah kepada nilai-nilai Islam. Senantiasa menempatkan segenap kamauan, perasaan, pemikiran, serta perilakunya di bawah aturan Islam; 3) Ihsan, yakni merasa selalu diawasi oleh Allah swt sehingga selalu berakhlak mulia, baik dalam hubungannya dengan Allah Swt, dengan sesama manusia, maupun dengan lingkungan sekitar; 4) Izzah, memiliki perasaan bangga menjadi seorang muslim di manapun dia berada; 5) Tasammuh, memiliki sikap toleransi yang tinggi dalam menghadapi pluralitas/ kemajemukan beragama serta keberagaman pemikiran dan buadaya; 6) Tawadhu, rendah hati dan bersikap hormat terhadap orangtua, guru, dan kepada setiap orang yang sepatutnya dihormati; 7) Sidik dan amanah, bersikap jujur dan professional dalam segala hal berdasarkan keyakinan bahwa jujur dan professional adalah sebuah keniscayaan; 8) Tabligh dan fathanah, komunikatif, transparan, dan visioner; 9) Fastabiqul khairat, mampu mengikuti kelebihan orang lain, dan siap untuk bersaing secara sportif dalam rangka mencapai prestasi dan prestige terbaik; dan 10) Khaira Ummah, merasa terpanggil untuk menjadi pelopor segala kebaikan bagi umat Islam, bangsa, dan manusia secara keseluruhan.

Materi inti mata kuliah PAI yang diberikan di ITB meliputi: Aqidah, Syariah, dan Akhlak. Topiktopik yang disampaikan di kelas dikelompokkan ke pada empat katagori, yaitu: Pertama, Materi Pengantar; memaparkan hubungan hukum al-Qur'an sebagai Syari'ah dengan Hukum Alam atau Sunatullah. Di dalamnya dibahas pula tentang hirarki hukum (hukum agama, hukum alam, hukum akal, hukum wadh'i, dan hukum adat). Materi pengantar ini berisi pula konsep alam dan manusia.

Kedua, Materi Sumber Ajaran Islam (SAI); materi ini berisi pemaparan tentang sumbersumber ajaran Islam, yakni al-Qur'an dan AsSunnah serta Ijtihad. Sehingga mahasiswa dapat memahami standing position al-Qur'an sebagai pedoman aturan hidup berada paling atas melebihi segala aturan yang ada. Aturan al-Qur'an itu bersifat global, oleh karena itu harus dijelaskan dengan Sunnah Rasulullah SAW. Dalam hal ini Rasulullah Saw berfungsi sebagai whole model (uswah hasanah). Selanjutnya dalam hal-hal yang kurang jelas, baik di dalam al-Qur'an maupun 
Hadits, ditetapkan melalui Ijtihad. Sebuah metode penetapan hukum bagi sesuatu yang belum jelas dan tegas baik dalam al-Qur'an maupun dalam al-Hadits, melalui serangkaian kerja nalar, dengan menganalisa dalil-dalil implisit yang berkenaan dengan persoalan yang dicari hukumnya.

Ketiga, Materi Etika atau Akhlak; merupakan aplikasi dari nilai-nilai Islam dalam kehidupan. Etika dibagi menjadi empat bagian, yakni etika kepada Allah, etika kepada sesama manusia, etika kepada alam sekitar, serta etika terhadap diri sendiri. Di dalamnya termasuk etika pengembangan sains, teknologi dan seni. Keempat, materi pengayaan yang berfungsi untuk memperkaya khazanah keilmuan mahasiswa, antara lain berisi pemaparan tentang paham dan aliran Islam, studi kritis tentang tasawuf dan tarekat, serta pembahasan tentang ilmu supra rasional.

Materi-materi tersebut mengacu pada Dirjen Pendidikan yaitu: Akidah, Syariah dan Akhlak yang dijabarkan berdasarkan SK Dikti No.38 tahun 2002, yang dijabarkan pada Rencana Program Pengajaran. Pelaksanaan perkuliahan Pendidikan Agama Islam di ITB, sering digabungkan dari berbagai jurusan. Jumlah mahasiswa perkelas antara 50 s.d. 60. Kecuali jurusan Teknik Sipil dan Elektro tidak digabungkan (menyelenggarakan kelas sendiri). Pelaksanaan perkuliahan, selain melalui tatap muka di kelas, juga dilakukan diskusi kelas, tugas terstruktu membuat makalah yang sesuai dengan topik dan silabi perkuliahan PAI ditambah dengan praktek ibadah yang dibimbing langsung oleh Assisten dosen.

Jumlah pertemuan di kelas dalam satu semester 14 kali ditambah 2 kali untuk ujian (UTS dan UAS) di samping pertemuan di kelas mahasiswa harus mengikuti asistensi yang dijadwalkan sesuai kesepakatan asisten dan mahasiswa dan bertempat di Mesjid Salam ITB. Akhir dari perkuliahan atau asistensi diadakan kegiatan berupa Studi Islam Intensif (SII).

Strategi pembelajaran PAI yang digunaan di ITB adalah memadukan seluruh potensi yang ada, antara lain: kompetensi dosen guru, potensi mahasiswa, sumber-sumber pembelajaran (perpustakaan, internet, expert, dll), media pembelajaran (lap top, infocus, email, dll), metode pembelajaran, serta system evaluasi terpadu. Semuanya dipersiapkan dan dilaksnakan secara transparan, obyektif, dan berkesinambungan.

$\mathrm{Hal}$ tersebut sejalan dengan pendapat Imran Siregar (2014: 51), yang mengatakan bahwa pelaksanaan perkuliahan PAI di Perguruan Tinggi memerlukan suasana interaksi antara dosen dan peserta didik yang lebih intens. Figur dosen agama Islam tidak sekedar sebagai pengampuh dan penyampai materi kuliah tetapi lebih dari itu ia adalah sumber inspirasi "spiritual" sekaligus pembimbing sehingga terjalin hubungan pribadi antara dosen dan peserta didik yang cukup dekat dan mampu melahirkan perpaduan bimbingan antara rohani dan akhlak dengan materi pembelajarannya. Sampai di sini fungsi dan peran dosen PAI tidak melulu hanya bermodalkan profesionalitas sesuai undang-undang guru dan dosen yang mencakup kompetensi kepribadian, pedagogik, sosial dan professional, namun juga perlu didukung oleh kekuatan moral atau akhlak.

Pendekatannya PAI di ITB cenderung theologis dengan menggunakan pendekatan rasional. Metode pengajarannya berupa ceramah, diskusi, multimedia dan praktek (praktek ibadah dan mentoring) yang disesuaikan dengan medan ITB. Uraian di atas menggambarkan bahwa secara formal, bahwa kebijakan-kebijakan yang berkaitan dengan pembelajaran mata kuliah PAI di ITB, telah diimplementasikan sesuai dengan perencanaan yang ditetapkan sebelumnya.

\section{Hubungan Kelembagaan antara Lembaga Sostek ITB dengan Mesjid Salman, dan UKM GAMAIS}

Menurut Yedi Purwanto dan Cecep Alba (Dosen PAI), secara formal pembelajaran PAI dilakukan oleh lembaga Sosio-Teknologi ITB. Namun demikian, keberadaan Mesjid Salman sebagai media dakwah sangat efektif, karena orangorang salman itu adalah orang-orang ITB yang memiliki integritas dan kepedulian terhadap agama Islam. Di Mesjid Salman dilakukan mentoring, memantau kemampuan mahasiswa dalam bacaan al-Qur'an, shalat, dan akhlak secara keseluruhan. Dengan cara ini, mahasiswa akan memahami besaran nilai PAI yang diperolehnya, dan tidak ada complain (Wawancara, Kamis tanggal 3 Agustus 2012).

Mesjid Salman ITB di bawah binaan Yayasan Salman, yang di angkat pengelolanya oleh ITB, sehingga hampir semua pengelola Yayasan Mesjid Salman adalah orang-orang ITB. Kecuali beberapa orang luar yang mendapat persetujuan dari Rektor ITB. Secara institusi atau struktural Yayasan Mesjid Salman tidak ada kaitan dengan program pembelajaran PAI di ITB. Namun secara fungsional atau de facto katerkaitannya erat sekali.

Hal itu bisa dilihat, dari kontribusi Yayasan mesjid Salman ITB dalam pembinaan keagamaan (Islam) bagi mahasiswa ITB yang sangat besar. Menurut Suwarno (Ketua Divisi Pelayanan dan 
Dakwah) dan Arie (Manager Divisi Kemahasiswaan dan Kaderisasi), para mahasiswa mengikuti program PAI di Mesjid Salman atas dasar sukarela. Sehingga tidak ada sanksi dan tidak berpengaruh pada nilai hasil ujian di kelas. Namun demikian, para dosen dan asisten dosen tetap memberi teguran kepada mahasiswa ITB yang tidak ikut aktif dalam mengikuti pembinaan agama Islam di Mesjid Salman (Wawancara, Rabu, 03 Juli 2012).

Kurikulum PAI di ITB sama seperti pada perguruan tinggi lainnya. Jika dilihat dari segi kuantitas dosen tidak memadai, tetapi dioptimalkan oleh assistensi sesuai dengan jumlah mahasiswa atau kelasnya. Para asisten yang diambil dari tenagatenaga muda yang antusias dan interes tinggi terhadap pendalaman agama. Peran mereka terutama dalam mengevaluasi bacaan al Qur'an, tata-cara dan bacaan shalat, thaharah dan lain lain. Di sini para dosen menyiapkan diri untuk berdialog dan berdiskusi tentang masalah masalah keislaman kontempoter, studi kasus atau masalah yang sedang berkembang di masyarakat. Sehingga terjalin komunikasi intensif komplementif antara dosen dan mahasiawa.

Dalam bagian lain,, Edwin Riswandi (Lulusan Geologi 1992) dan Arry Setya (Lulusan Science Biologi 2007) menambahkan bahwa materi Kuliah Agama (Agama dan Etika) sebanyak 2 SKS yang dilaksanakan dalam tatap muka di kelas wajib diikuti oleh setiap mahasiswa, sedangkan sistem asistensi melibatkan mahasiswa yang diangkat oleh dosen bersangkutan untuk melakukan mentoring di Salman dengan materi Kajian Agama dan Training BTQ serta praktek ibadah (Wawancara, Rabu 11 Juli 2012).

Mentoring berlangsung setelah tausiyah selesai dengan kelompok-kelompok yang sudah ditentukan sebelumnya. Tiap kelompok didampingi oleh satu orang mentor yang akan memberikan materi-materi rohani dengan jadwal yang sudah disepakati tiap kelompok. Dalam rangka menambah pengetahuan agama, dan mengumpulkan kelompok mentoring, para mahasiswa yang mengambil mata kuliah wajib Asistensi Agama dan Etika Islam (AAEI) diwajibkan untuk datang pada acara mentoring akbar dan tahsin.

Di samping Mesjid Salman sebagai media pembinaan Pendidikan Agama Islamdi ITB adalah Unit Kegiatan Mahasiswa (UKM) yang diberi nama Gamais (Gabungan Mahasiswa Islam). Gamais adalah sebuah usaha dari kader ITB untuk menyusun agenda dakwah secara sistematis, terarah, dinamis, sinergis serta harmonis. Dengan sebuah harapan bahwa dakwah di kampus ITB bisa berkelanjutan dan bertahap mencapai sebuah cita-cita besar. Blue print ini berisikan pandangan, pemikiran, serta langkah-langkah strategis yang dijalankan Gamais dalam mencapai sebuah keberhasilan amal di kampus ITB. Blue print ini disusun dalam rangka menurunkan cita-cita besar Gamais di masa yang akan datang dan diharapkan bisa menjadi landasan dalam menyusun dan merangkai agenda dakwah di kampus ITB.

Gamais berdiri akibat adanya berbagai tantangan yang dihadapi mahasiswa muslim pada masa awal tahun 80an. Kala itu bisa dikatakan kegiatan di dalam kampus ITB di dominasi oleh kelompok yang tidak akrab dengan kegiatan keislaman. Sebagian aktivis kampus saat itu bahkan secara terang-terangan menyatakan diri sebagai "kelompok kiri" yang cenderung sosialis atau marxis.

Sementara itu, sebagai akibat berbagai pelatihan yang menjangkau kalangan pelajar dan mahasiswa, banyak mahasiswa angkatan 80 -an yang telah memiliki idealisme keislaman ketika memasuki jenjang kuliah. Mereka yang masuk ke ITB mendapati bahwa ternyata hampir tidak ada ruang bagi mahasiswa muslim untuk mengekspresikan keislamannya di dalam kegiatan kemahasiswaan di kampus ITB.

Upaya pertama yang dijalankan para mahasiswa muslim adalah dengan mengadakan berbagai pengajian kecil di lingkungan jurusan yang disebut "usroh", yang paling aktif dalam model kegiatan ini adalah kalangan angkatan 85 pada masa TPB. Dari berbagai komunikasi antar aktifis dari berbagai usroh jurusan, dicapailah sebuah kesepakatan untuk membuat sebuah kegiatan keislaman di kampus ITB. Maka dibentuklah panitia peringatan Isra'Mi'raj di kampus ITB. Panitia tersebut sepenuhnya mendapatkan dukungan dari aktifis muslim dari berbagai angkatan, khususnya angkatan 83 dan 84. Kegiatan di atas sukses dan menjadi tonggak baru bahwa di kampus ITB bisa diadakan kegiatan keislaman.

Dari berbagai komunikasi antar angkatan pula akhirnya dirancang sebuah kegiatan penting, yaitu Pesantren Mahasiswa. Acara ini dilaksanakan pada masa liburan panjang bulan Juni dan Juli 1986 di Pondok Pesantren At Taqwa di Ujung Harapan, Bahagia, Bekasi. Pesantren mahasiswa ini sepenuhnya dalam bimbingan dari tim yang dibentuk oleh Dewan Dakwah Islamiyah Indonesia (DDII) yang kala itu di bawah pimpinan Bapak Muhammad Natsir. Perhatian besar beliau dalam mendukung acara pesantren itu menyebabkan kegiatan bisa dijalankan hampir 2 bulan lamanya. Para peserta dalam pesantren mahasiswa 
inilah yang nantinya menjadi motor berdirinya Gamais ITB.

Usai kegiatan ini, angkatan baru datang di kampus ITB, yaitu angkatan 86. Sejatinya kedatangan angkatan inilah yang memaksa munculnya Gamais. Kesolidan angkatan ini dalam wadah Keluarga Mahasiswa Muslim 86 (KMM 86) sepanjang menjalani masa TPB mendorong para aktifis eks-pesantren mahasiswa membuat inisiatif besar. Adalah Herry Meoljanto (FT'83) yang mengkampanyekan pertama kali tentang perlunya wadah organisasi mahasiswa Islam di Kampus ITB. Salah satu momen kampanyenya bahwa sering dikenang sebagai sumpah setia pendirian Gamais ITB dilakukan di bawah menara Salman.

Pertemuan besar menginisiasi munculnya organisasi mahasiswa Islam ITB dilakukan di rumah kos Jauharul Fuad (TI'83). Antusiasme terlihat dengan datangnya sekitar 100 mahasiswa muslim dalam acara ini. Disepakati akan dilakukan pembentukan organisasi mahasiswa muslim ITB melalui sebuah kongres di BLKP Lembang. Untuk mempersiapkannya dibentuk tim perumus AD/ART yang terdiri atas 5 orang, yaitu Heru Prabowo (EL'83), Munawar Kholil (IF'85), Yusri Suhud (MA'85), Budi Hartono (FT'86), dan Budi Youyastri (Si'86). Tim yang dipimpin Munawar Kholil ini berhasil menyusun draft AD/ART sesuai yang direncakan.

Pada akhirnya momen penting sejarah terjadi. Kongres dilaksanakan di BLKP Lembang pada 29-30 Agustus 1987. Kebersamaan yang luar biasa menyebabkan proses pengesahan $\mathrm{AD} / \mathrm{ART}$ berjalan sangat lancar, termasuk pemilihan nama Gamais ITB yang dihasilkan dari proses diskusi yang hangat. Tepat Tengah Malam, Ahad, 30 Agustus 1987, Gamais ITB berdiri bersama dengan pekik takbir yang membahana. Keesokan pagi dan sianganya, perangkat organisasi Gamais ITB angkatan pertama terbentuk. Jaka Sumanta (IF'85) terpilih sebagai Kepala Gamais ITB yang pertama, sedangkan Munawar Kholil (IF'85) terpilih sebagai Ketua MPAS (Majelis Permusyawaratan Anggota Sementara).

Organisasi ini menjadi lokomotif perubahan, karena Gamais inilah mahasiswa Islam mendiskusikan masalah-masalah agama secara intensif. Literatur keagamaan di lingkungan aktivis Gamais sebagai lembaga dakwah kampus dan kajian Islam masih didominasi oleh penulis-penulis yang berafiliasi dengan Ikhwanul Muslimin dan ideologi khilafah Hizbut Tahrir. Ini ditunjukkan dari daftar rujukan Panduan Mentoring, tokoh-tokoh yang menjadi rujukan dalam literatur yang dibaca, hal itu dibuktikan dengan ditemukan dari 20 judul buku yang dibaca, penulis yang berafiliasi ideologis pada ideologi khilafah adalah yang sering dibaca (Iswanto, 2017: 25).

Berdasarkan analisis terhadap keberadaan ketiga lembaga di atas dan hasil wawancara dengan Samsoe Basarudin dan Johansyah (Sekretaris dan Sesepuh Mesjid Salman), Suwarno (Ketua Divisi Pelayanan dan Dakwah) dan Arie (Manager Divisi Kemahasiswaan dan Kaderisasi) diperoleh data sebagai berikut:

"Yayasan Mesjid Salman, dilihat dari perspektif sejarahnya tidak bisa dipisahkan dari ITB. Karena Mesjid Salman merupakan sentral kegiatan keagamaan kampus ITB. Tetapi secara struktural institusional dan badan hukum mereka terpisah. Yayasan Mesjid Salman merupakan badan independen yang secara formal kegiatan-kegiatannya tidak berhubungan dengan kegiatan akademik mahasiswa ITB (non SKS dan merupakan kesadaran individu masing-masing). Namun dalam pembentukkan karakter muslim sesuai dengan tujuan pembelajaran PAI di ITB, tidak bisa dinisbikan. Bahwa keberadaan Mesjid Salman serta kegiatan kegiatannya turut serta mewarnai kehidupan dan pemahaman keagamaan mahasiswa ITB. Karena mayoritas dari mulai pengurus, pembina dan pengawas di yayasan Mesjid Salman adalah dosen-dosen dan mahasiswa ITB (sekalipun tidak ada aturan secara tertulis tatapi berjalan dengan baik, hanya berupa SK dari Salman). Dosen-dosennya selalu memberi motivasi dan mendukung terhadap mahasiswanya untuk mengikuti kegiatan kegiatan yang ada di Salman". (Wawancara, Rabu 03 Juli 2012)

Adapun UKM Gamais berperan dalam mengorganisir para aktifis dakwah kampus di ITB, membina para mahasiswa ITB kemudian mendistribusikannya di posisi-posisi yang bisa berpengaruh pada masyarakat kampus. UKM Gamais, juga turut berperan serta dalam penyampaian pemikiran Islam secara masif dan khusus. UKM Gamaislah yang mengkoordinir semua elemen dakwah kampus di ITB dari mulai tingkat Prodi, Fakultas sampai pada tingkat Institut.

Jika dilihat dari segi hubungan fungsional kelembagaan antara Sostek ITB, Yayasan Mesjid Salman dan UKM Gamais dalam pembelajaran 
Pendidikan Agama Islam di ITB dapat dilihat pada gambar di bawah ini.

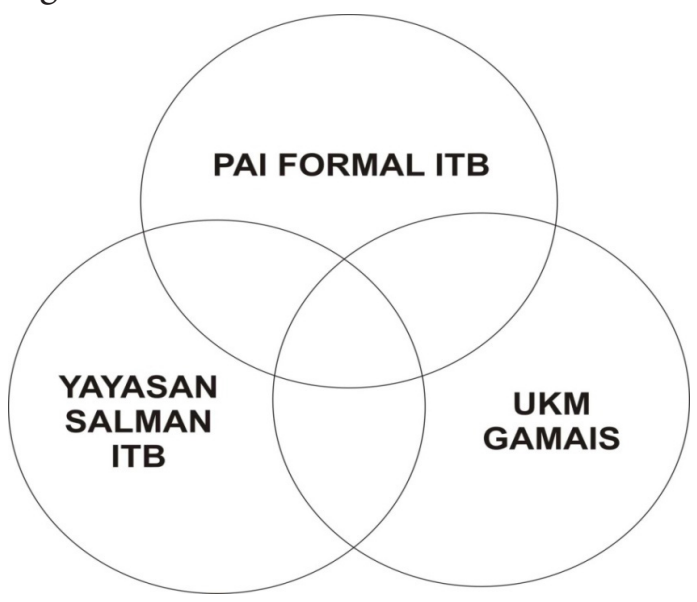

Berdasarkan analisis di atas, dapat di katakan bahwa secara keseluruhan keberhasilan pembelajaran Pendidikan Agama Islam di ITB tidak terlepas dari fungsi-fungsi kelembagaan tersebut. Secara fungsional ketiga lembaga tersebut di atas, (Sostek-ITB, Yayasan Mesjid Salman dan UKM Gamais) masing-masing memiliki keterlibatan yang cenderung cukup dalam. Sehingga, andil kedua lembaga (Yayasan Mesjid Salman dan UKM Gamais) dalam membentuk karakter para mahasiswa ITB sangat berarti dan memadai.

\section{PENUTUP}

Berdasarkan temuan dan pembahasan diatas dapat diambil kesimpulan sebagai berikut: Pertama, pengelolaan pembelajaran mata kuliah Pendidikan Agama Islam di ITB berada di bawah Sostek (Sosio Teknologi) ITB, karena mata kuliah tersebut berada dalam wilayah kajian sosio (Humaniora), sama dengan mata kuliah bahasa. Mata kuliah Pendidikan Agama Islam termasuk mata kuliah MKDU (Mata Kuliah Dasar Umum) dan disebut juga MPK atau Mata Kuliah Kepribadian Sub. Bidang Agama.

Kedua, implementasi proses pembelajaran Pendidikan Agama Islam di ITB secara institusional mengacu pada Sistem Pendidikan Nasional (SK Dirjen Dikti Depdiknas RI tahun 2006 Nomor 43/Diktil Kep/2006). Tujuannya ingin mencetak peserta didik (mahasiswa) untuk menguasai sains dan teknologi dengan memiliki kepribadian orang yang bertakwa, sesuai visi dan misi Islam yang Rahmatan lil'alamiin. Secara formal mata kuliah Pendidikan Agama Islam diberikan hanya satu semester, yaitu pada semester III, dengan beban 3 SKS ( 2 SKS digunakan untuk tatap muka di kelas, 1 SKS lagi digunakan untuk prktek ibadah dan mentoring). Seluruh mahasiswa wajib mengikuti mata kuliah PAI di semester yang sama tetapi kalau bentrok boleh memilih jam dan kelas yang berbeda.

Perencanaan pengajaran tertuang dalam RPP dan materinya mengacu pada DIRDIK (Dirjen Pendidikan) yaitu: Akidah, Syariah dan Akhlak yang dijabarkan berdasarkan SK Dikti No.38 tahun 2002. Metode pembelajarannya berupa ceramah, diskusi, multimedia dan praktek (praktek ibadah dan mentoring) yang waktu dan tempatnya fleksible disesuaikandenganmedanITB.Sedangkan pendekatan yang digunakannya cenderung theologis tidak terjebak dalam pemikiran fiqih, tapi sangat kuat dengan pendekatan rasional. Adapun strategi pembelajaran yang digunaan adalah memadukan seluruh potensi yang ada, kompetensi guru, potensi mahasiswa, sumber-sumber pembelajaran (perpustakaan, internet, expert, dll), media pembelajaran (lap top, infocus, email, dll), serta siystem evaluasi terpadu. Semuanya dipersiapkan dan dilaksnakan secara transparan, obyektif, dan berkesinambungan.

Ketiga, Hubungan kelembagaan antara ITB, Yayasan Mesjid Salman dan Gamais dalam proses pembelajaran Pendidikan Agama Islam (PAI) di ITB memiliki hubungan dan kontribusi yang sangat besar dalam membentuk karakter para mahasiswa ITB, meskipun secara formal tidak ada kaitan atau hubungan struktural.

\section{UCAPAN TERIMA KASIH}

Tulisan yang ada ditangan sidang pembaca ini tidak terlepas dari kontribusi berbagai pihak, oleh sebab itu penulis megucapkan terima kasih kepada segenap akademika ITB yang telah memberi kemudahan dalam proses pengumpulan data, wabilkhusus kepada H. M. Rahmat Effendi, M.Pd.I dan Asep Dudi Suhardini, S.Ag.,M.Pd yang telah membantu proses pengumpulan data sehingga memperkaya temuan penelitian juga kepada Drs. $\mathrm{H}$. M. Amin Thaib yang telah memfasilitasi penelitian dan memberikan arahan sampai selesai karya tulis ini. Terima kasih juga kepada Kepala Balai Litbang Agama Jakarta yang telah membiayai penelitian ini melalui dana DIPA.

\section{DAFTAR PUSTAKA}

Al-Quran dan Terjemahnya, Tt. Mujamma’ al-Malik Fahd Li Thibaat Al-Mushhaf Asy-Syarif, Madinah AlMunawaroh.

Amirin. 1996. Pokok-pokok Teori Sistem. Jakarta: Rajawaii Pers 
Anshari, Zainal. 2012. Pendidikan Agama Islam Di Perguruan Tinggi Umum (Studi Historis dan Realitas Pendidikan Agama Islam di Perguruan Tinggi Umum). Edu Islamika, Volume 4, Nomor 01, Maret, hal. 56-84.

Danim, Sudarwan 1997. Pengantar Studi Penelitian Kebijakan, Bumi Aksara, Jakarta.

Daradjat, Zakiyah. 1993. Pengantar Ilmu Jiwa Agama. Jakarta; Bulan Bintang.

Edward III, Merilee S. 1980. Implementing Public Policy. Washington: Congressional Quarterly Press.

Gunawan, Imam. 2013. Metode Penelitian Kualitatif: Teori dan Praktik. Jakarta: Bumi Aksara.

Hidayatulloh, Furqon Syarief. 2013. Manajemen Pendidikan Agama Islam Di Perguruan Tinggi Umum (Studi Kasus di Institut Pertanian Bogor). Jurnal Pendidikan Islam. Volume XXVIII, Nomor 2, hal. 186-202.

Iswanto, Agus. 2017. Ideologi dalam Literatur Keagamaan pada Aktivis Dakwah Kampus dan Kajian Islam di ITB Bandung. Jurnal SMaRT, Volume 3, Nomor 1 Juni, hal. 13-28.

Kahmad, Dadang. 1999. Metode Penelitian Agama (Perspektif Ilmu Perbandingan Agama), Bandung: Pustaka Setia.

Keluaga Mahasiswa Islam (GAMAIS ITB), 2007 M /1428 H. Anggaan Dasar (AD) / Anggaan Rumah tangga (ART), Bandung: Insitut Teknologi Bandung

Munip, Abdul. 2008. Perkuliahan Pendidikan Agama Islam Diperguruan Tinggi Negeri (Sebuah Catatan Lapangan). Jurnal Pendidikan Agama Islam, Volume V, Nomor 1, hal. 15-42.

Muslim, Ahmad Buchori. 2016. Model Pengembangan Pendidikan Agama Islam di Perguruan Tinggi Umum (Studi Multisitus di Universitas Brawijaya dan Universitas Negeri Malang), Tesis, Magister
Pendidikan Agama Islam, Malang: Universitas Maulana Malik Ibrahim.

Moleong, Lexy J. 2009. Metodologi Penelitian Kualitatif. Bandung: PT. Rosdakarya.

Nasikiun. 1996. Sistem Sosial Indonesia. Jakarta: C.V. Rajawait. Parson, A Talcott. 1994. Sosiologi Kontemporer. Jakarta: PT. Raja Grapindo Persada.

Saepudin, Juju. 2015. Kapasitas Kopertais Wilayah XIII Dalam Meningkatkan Mutu PTAIS Di Provinsi Jambi. Jurnal “Al-Qalam", Volume 21, Nomor 2 Desember, hal. 277-290.

Saepudin, Juju. 2015. Model Pembelajaran Dalam Perspektif Ibnu Khaldun: Resepsi Terhadap Kitab Muqaddimah. Jurnal Edukasi, Volume 13, Nomor 2, Agustus 2015, hal. 222-238.

Setyadi, Iwan Tritenty. 2005. Evaluasi Implementasi Proyek Inovasi Manajemen Perkotaan Pekerjaan Pemberdayaan Sektor Informal Pedagang Kaki Lima Kota Magelang. Tesis. Yogyakarta: MPKD Universitas Gadjah Mada.

Siregar, Imran. 2014. Model Pengajaran Agama Islam di Universitas Sumatera Utara (USU) Medan. Jurnal "Al-Qalam", Volume 20, Nomor 1 Juni, hal. 45-56.

Siregar, Imran. 2016. Aspirasi Mahasiswa Terhadap Pembelajaran Pendidikan Agama Islam di Perguruan Tinggi Umum: Kasus Mahasiswa FIP UPI. Bandung. Jurnal Penamas Volume 29, Nomor 2, Juli-September, hal. 265 - 278.

Sulaiman, Rusydi. 2015. Pendidikan (Agama) Islam di Perguruan Tinggi: Tawaran Dimensi Esoterik Agama Untuk Penguatan SDM. Jurnal Madania, Volume 19, Nomor 2 Desember, hal. 223-230.

Zamroni. 1992. Pengantar Pengembangan Teori Sosial. Tiara Wacana: Yogyakarta. 